Yutaka Kitamura • Kaori Minobe • Tomoko Nakata

Kazuo Shimizu • Shigeo Tanaka • Minoru Fujimori

Shiro Yokoyama · Koichi Ito • Masahiko Onda

Mitsuru Emi

\title{
Ret/PTC3 is the most frequent form of gene rearrangement in papillary thyroid carcinomas in Japan
}

Received: November 24, 1998 / Accepted: November 28, 1998

\begin{abstract}
Rearrangements of the RET and TRK protooncogenes, which generate fusion oncogenes, are frequent in papillary thyroid carcinomas in Caucasian populations. To determine the spectrum of gene rearrangements in Japanese patients, we systematically examined 40 papillary thyroid carcinomas for all possible types of gene fusion events involving $R E T$ or $T R K$ genes. RET rearrangements were found in ten tumors (25\%): ret/PTC1 had occurred in two tumors, ret/PTC2 in one, ret/PTC3 in six, and a novel $R E T$ rearrangement in the remaining patient. In this last patient, the $5^{\prime}$ novel sequence was fused in-frame to the RET amino acid sequence; thus, the fusion gene may encode a protein with a RET kinase domain at the carboxy terminus. The $R E T$ gene was fused to $5^{\prime}$ donor sequences at the beginning of exon 12 in all ten tumors. No rearrangements involving the $T R K$ gene were found in this panel of carcinomas. Our results indicated that constitutive activation of the RET by gene rearrangement is a frequent mechanism of papillary thyroid carcinogenesis in Japanese adults.
\end{abstract}

Key words $R E T$ proto-oncogene $\cdot T R K$ proto-oncogene • Papillary thyroid carcinoma $\cdot$ Rearrangement

Y. Kitamura $\cdot$ K. Minobe $\cdot$ T. Nakata $\cdot$ M. Emi $(\square)$

Department of Molecular Biology, Institute of Gerontology, Nippon Medical School, 1-396 Kosugi-cho, Nakahara-ku, Kawasaki 211-8533, Japan

Tel. +81-44-733-5230; Fax +81-44-733-5192

e-mail: memi@nms.ac.jp

Y. Kitamura $\cdot$ K. Shimizu $\cdot$ S. Tanaka

Department of Surgery II, Nippon Medical School, Tokyo, Japan

K. Minobe $\cdot$ M. Onda

Department of Surgery I, Nippor Medical School, Tokyo, Japan

M. Fujimori · S. Yokoyama

Second Department of Surgery, Shinsyu University School of

Medicine, Nagano, Japan

K. Ito

Ito Hospital, Tokyo, Japan

\section{Introduction}

The inactivation of tumor suppressor genes and the activation of oncogenes play important roles in the carcinogenesis of a variety of solid tumors in humans (Nakamura 1993; Nakamura 1996), while chromosomal rearrangements that produce chimeric oncogenes are occasionally associated with hematologic malignancy and some sarcomas (Rabbits 1994). An exception to this general pattern is seen in one type of carcinoma, papillary thyroid carcinoma, in which rearrangements of tyrosine kinase domains in the $T R K$ and $R E T$ proto-oncogenes occur with more than random frequency (Bongarzone et al. 1989). The TRK proto-oncogene is a receptor for nerve growth factor (Klein et al. 1991); the $R E T$ proto-oncogene product forms a receptor-complex for glial cell line-derived neurotrophic factor (GDNF) (Jing et al. 1996) and neurturin (NTN) (Klein et al. 1997). TRK chimeric oncogenes are generated by juxtaposition of the tyrosine kinase domain of the TRK proto-oncogene on chromosome $1 \mathrm{q}$ to $5^{\prime}$ end sequences of different donor genes. The three forms of $T R K$ oncogenes found to date are TRK, TRK-T1, and TRK-T3, which, respectively, involve fusion to the tropomyosin gene on 1q (Martin-Zanca et al. 1986), to the translocated promoter region (TPR) on $1 \mathrm{q}$ (Greco et al. 1992), and to the TRK-fused gene (TFG) on chromosome 3 (Greco et al. 1995). RET chimeric oncogenes (ret/PTC oncogenes) encode fusion proteins in which RET tyrosine kinase domains are fused to $5^{\prime}$ end sequences of different donor genes. Three forms of the ret/ PTC oncogene have been identified, ret/PTC1, ret/PTC2, and ret/PTC3; in these forms the RET proto-oncogene is fused, respectively, to the $H 4$ gene on chromosome $10 \mathrm{q} 21$ (Grieco et al. 1990), to the regulatory subunit RI $\alpha$ of the cyclic adenosine monophosphate (cAMP) dependent protein kinase A gene on 17q23 (Bongarzone et al. 1993), and to the Ele 1 gene on 10q11.2 (Bongarzone et al. 1994; Jhiang et al. 1994; Santoro et al. 1994).

Ret/PTC oncogenes have been reported in more than $34 \%$ of papillary thyroid carcinomas examined in European populations (Bongarzone et al. 1989; Viglietto et al. 1995; 
Williams et al. 1996). These phenomena have seldom been detected in papillary thyroid carcinomas (less than $3 \%$ ) in Japan, although until now Japanese investigators have examined this type of carcinoma only for the ret/PTC1 chimeric gene (Namba et al. 1991; Wajjwalku et al. 1992). The discrepancy in the reported frequency of ret/PTC oncogenes could be due to environmental, racial, or methodological factors. To establish the frequency of RET and $T R K$ activation in papillary thyroid carcinomas in Japan and to understand the molecular basis for the apparent differences among populations, we screened 40 papillary thyroid carcinomas from Japanese patients and characterized all possible types of rearrangements involving $R E T$ and $T R K$ genes, using advanced techniques of $5^{\prime}$-rapid amplification of cDNA ends (RACE) and the reverse transcriptase-polymerase chain reaction (RT-PCR).

\section{Patients and methods}

Tumor samples and RNA extraction

Papillary thyroid carcinomas were obtained from 40 adult patients during surgery. The specimens were frozen immediately and stored at $-70^{\circ} \mathrm{C}$ until analysis. Total RNA was extracted by the guanidine thiocyanate method (Chomczynski and Sacchi 1987), using an Isogen RNA extraction kit (Nippon Gene, Tokyo, Japan).

PCR primers and hybridization probes

The sequences of the oligonucleotide primers (T1-T21) and the hybridization probes (A-H) used in the following experiments are listed in Table 1. The positions of these sequences on ret/PTC and TRK oncogenes are shown in Fig. 1.

\section{5' RACE procedures}

To screen for RET fusions, we used 5' RACE according to the improved method of Chen (1996). Briefly, $4 \mu \mathrm{g}$ of total RNA was reverse-transcribed with Superscript II (Life Technology, Rockbille, MD, USA) for $50 \mathrm{~min}$ at $42^{\circ} \mathrm{C}$ in a $40-\mu 1$ reaction mixture containing $50 \mathrm{mM}$ Tris- $\mathrm{HCl}(\mathrm{pH} 8.3)$, $75 \mathrm{mM} \mathrm{KCl}, 3 \mathrm{mM} \mathrm{MgCl} 2,10 \mathrm{mM}$ dithiothreitol (DTT), $0.5 \mathrm{mM} \mathrm{dNTP}$, and $5 \mathrm{pmol}$ of $R E T$ specific primer T1. The RNA was then digested with $4 \mathrm{U}$ of RNaseH (Takara, Tokyo, Japan) at $37^{\circ} \mathrm{C}$ for $30 \mathrm{~min}$. A single-stranded oligonucleotide adapter, T2, was ligated to the $3^{\prime}$ end of the first cDNA, using T4 RNA ligase (NEB, Beverly, MA, USA). The ligated cDNA was used as a template for the first PCR in a total volume of $10 \mu \mathrm{l}$ containing $30 \mathrm{mM}$ Tris- $\mathrm{HCl}(\mathrm{pH}$ $8.8), 50 \mathrm{mM}$ of $\mathrm{KCl}, 2 \mathrm{mM}$ of $\mathrm{MgCl}_{2}, 5 \mathrm{mM}$ of 2 mercaptoethanol, $100 \mu \mathrm{M}$ of each dNTP, $1.6 \mathrm{pmol}$ each of primers $\mathrm{T} 1$ and $\mathrm{T} 3$, and 0.25 units of Taq polymerase. Cycle conditions were $94^{\circ} \mathrm{C}$ for $2 \mathrm{~min}$, then 14 cycles of $94^{\circ} \mathrm{C}$ for $30 \mathrm{~s}, 62^{\circ} \mathrm{C}$ for $30 \mathrm{~s}$, and $72^{\circ} \mathrm{C}$ for $120 \mathrm{~s}$, with a final extension
Table 1 Oligonucleotide primers and probes used in this study

Primers

T1 5' CTTTCAGCATCTTCACGG 3'

T2 5' GTAGGAATTCGGGTTGTAGGGAGGTCGACATGCC 3'

T3 5' GGCAATGTCGACCTCCCTACAAC 3'

T4 5' CTCCCTAGAACCCGAATTTCCTAC 3'

T5 5' CGTTGCCTTGACCACTTTTC 3'

T6 5' CGGTAATAGTCGGTGCTGTA 3'

T7 5' CCTTGACAGCCACCAGCATC 3'

T8 5' GTCGGGGGGCATTGTCAT 3'

T9 5' GTTTTCGGTCTCCTTTATCG 3'

T10 5' TGGAGAAGAGTGGCTGTATC 3'

T11 5' CTTTCAGCATCTTCACGG 3'

T12 5' GCCTTCTCCTAGAGTTTTTC 3'

T13 5' GAGAACAAGGTGCTGAAGAT 3'

T14 5' AACCAGTGTTGGGGAAGGAG 3'

T15 5' TTGAGCGAATGGCTCCTTG 3'

T16 5' GTGTCTGAGTGCTGCCGAAGC 3'

T17 5' AGAAAGCAATACAACAAAGG 3'

T18 5' GTTATGGCAGCAAGTATGTC 3'

T19 5' CAAACTTGTTTCTCCGTCCAC 3'

T20 5' GGCACTCAGCAAGGAAGACC 3'

T21 5' AAGGAAGAGGCAGGCAAAGA 3'

Probes

Probe A 5' GAGGATCCAAAGTGGGAATT 3'

Probe B 5' TGGAGACCTACAAACTGAAGTGCAAGGCACTGC $3^{\prime}$

Probe C 5' TGTGGGGCATCGACCGAGACAGCTATAGAAGAA $3^{\prime}$

Probe D 5' AGCACCGACCCCCAGGACTGGCTTACCCAAAAG $3^{\prime}$

Probe E 5' TCAAGTGGGAGCTGGGGGAGGGCGCCTTTG 3' Probe $\mathrm{F}$ 5' GCTGAGTTTGCTGAGAGATCGGTACCAAGC 3' Probe G 5' AGCTTCTGATGTTTCTGTTAAGTATCGAGA 3' Probe H 5' AATGTTATGTCAGCGTTTGGCTTAACAGAT 3'

step $5 \mathrm{~min}$ at $72^{\circ} \mathrm{C}$, in a Gene Amp PCR 9600 System (Perkin Elmer Cetus, Foster City, CA, USA). Nested PCR was carried out with an annealing temperature of $55^{\circ} \mathrm{C}$ in 40 cycles, with primers $\mathrm{T} 4$ and $R E T$-specific primer T5. To screen $T R K$ fusions, 5' RACE was carried out using $T R K$ specific primer T6 and an inner TRK primer (T7), following the procedures described above.

\section{RT-PCR procedures}

RET gene. RT-PCR was carried out to detect the expression of chimeric ret/PTC1, ret/PTC2, and ret/PTC3 mRNAs. Five microliters of total RNA was reversetranscribed using $R E T$-specific primer $\mathrm{T} 1$, followed by digestion with RNaseH. The first PCR was done with sense primers (T8, T9, and T10) specific for the H4, RI $\alpha$, and Ele1 sequence, respectively, and the RET anti-sense primer T11, chosen to flank the breakpoint. Nested PCR was performed with inner primers of both RET (T12) and the respective fusion-gene sequences (T13, T14, and T15, corresponding to the H4, RI $\alpha$, and Ele1 sequences, respectively). The PCR conditions were as described above.

TRK gene. To detect the expression of chimeric TRK, TRK-T1, and TRK-T3 mRNAs, RT-PCR was performed following the procedures described above. Total RNA was reverse-transcribed using a $T R K$-specific primer (T6). The 
A. (5' RACE)

$R E T$ proto-oncogene

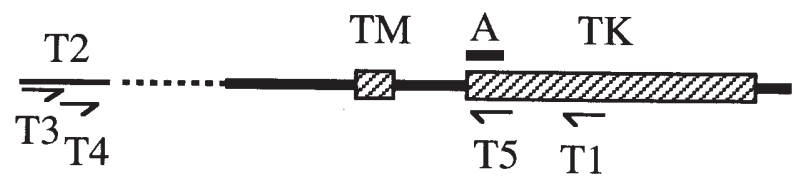

\section{B. (RT-PCR)}

ret/PTC1

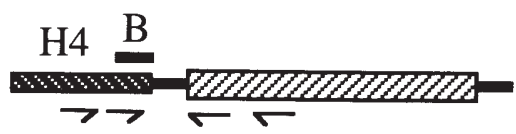

T8 T13 T12 T11

ret/PTC2

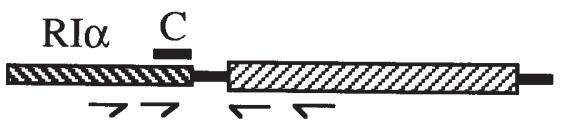

T9 T14 T12 T11

ret/PTC3

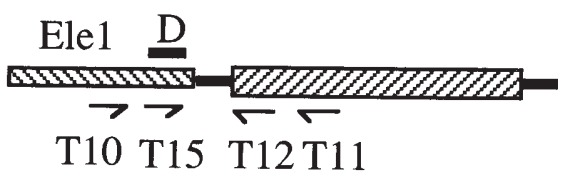

Fig. 1A,B Positions of oligonucleotide primers and hybridization probes on ret/PTC oncogenes and TRK oncogenes for A 5 '-rapid amplification of cDNA ends (RACE) and $\mathbf{B}$ reverse transcriptasepolymerase chain reaction (RT-PCR) procedures. Arrows indicate orientation of oligonucleotide primers (T1, T3-T21) and an adapter (T2).

first PCR employed anti-sense TRK primer T7 and the sense primers (T16, T17, and T18) specific for tropomyosin, TPR, and TFG sequence, respectively. Internal TRK primers T19, T20, and T21, together with donor-gene primers T16, T17, and T18, respectively, were used for nested PCR.

Oligonucleotide hybridization

The nested PCR products from the 5' RACE and RT-PCR experiments were electrophoresed on 3\% NuSieve agarose gels (FMC, Rockland, ME, USA) and transferred to nylon membranes. A RET gene-specific probe (A), $\mathrm{H} 4$ gene-specific probe (B), RI $\alpha$ gene-specific probe (C), Ele1 genespecific probe (D), TRK gene-specific probe (E), tropomyosin gene-specific probe $(\mathrm{F})$, TPR gene-specific probe $(\mathrm{G})$, and TFG gene-specific probe $(\mathrm{H})$ were each end-labeled with $\left[\gamma^{32} \mathrm{P}\right]$ ATP by T4 polynucleotide kinase. Hybridization of blotted membranes to oligonucleotide probes was performed according to the procedures described previously (Tsukamoto et al. 1998).

\section{$T R K$ proto-oncogene}

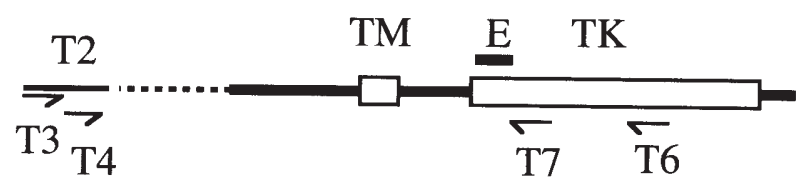

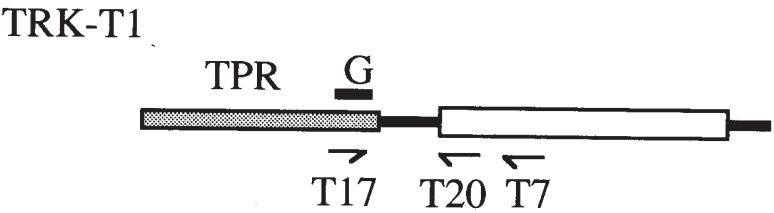

TRK-T3

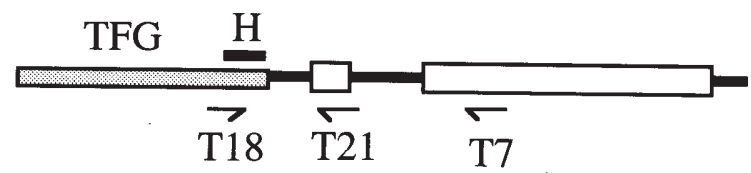

Short horizontal bars represent hybridization probes (probes A-H). TM box, Transmembrane domain; TK box, tyrosine kinase domain, $5^{\prime}$ end boxes, $5^{\prime}$ end sequences of donor genes for ret/PTC and TRK fusion genes

Sequence analysis

To characterize the structure of RET fusion transcripts, the $5^{\prime}$ RACE and RT-PCR products positive for hybridization were cloned into plasmid vector pBluescript II and sequenced with a Thermo-sequenase cycle sequencing kit (Amersham International Life Science, Cleveland, OH, USA).

\section{Results}

Total RNAs from 40 papillary thyroid carcinomas were first screened for the presence of ret/PTC oncogenes by $5^{\prime}$ RACE, according to the experimental strategies outlined in Fig. 1. In ten of the tumors, the 5' RACE products hybridized to a $R E T$-specific oligonucleotide probe (A) (cases 26, $28,56,60,70,76,80,86,88$, and 96). The same panel of tumors was then submitted to separate RT-PCR experiments, using the $R E T$-specific primer together with primers 
Fig. 2A Representative autoradiograms from RT-PCR, examined in Japanese papillary thyroid carcinomas. RT-nested PCR products of ret/ PTC1, ret/PTC2, and ret/PTC3 were shown to hybridize to H4, RI $\alpha$, and Ele1-specific probes, respectively. Arrowheads indicate cases positive for hybridization. B Sequence analysis of the ret/ PTC oncogene. A representative sequence of the ret/PTC3 transcript is shown. The fusion point is indicated by a horizontal arrow, where the $5^{\prime}$ end of RET exon 12 is fused to the $3^{\prime}$ end sequence of Ele1 exon 5. Vertical arrow indicates the direction of transcription
A
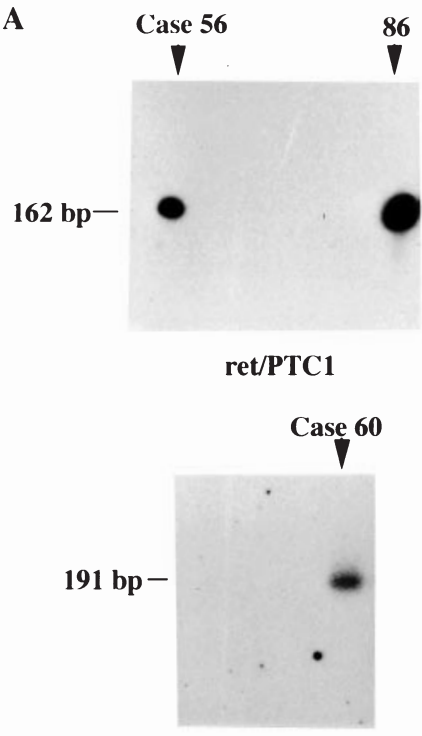

ret/PTC2

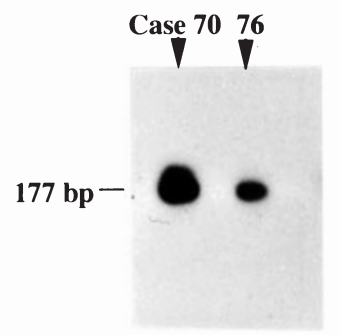

ret/PTC3
B

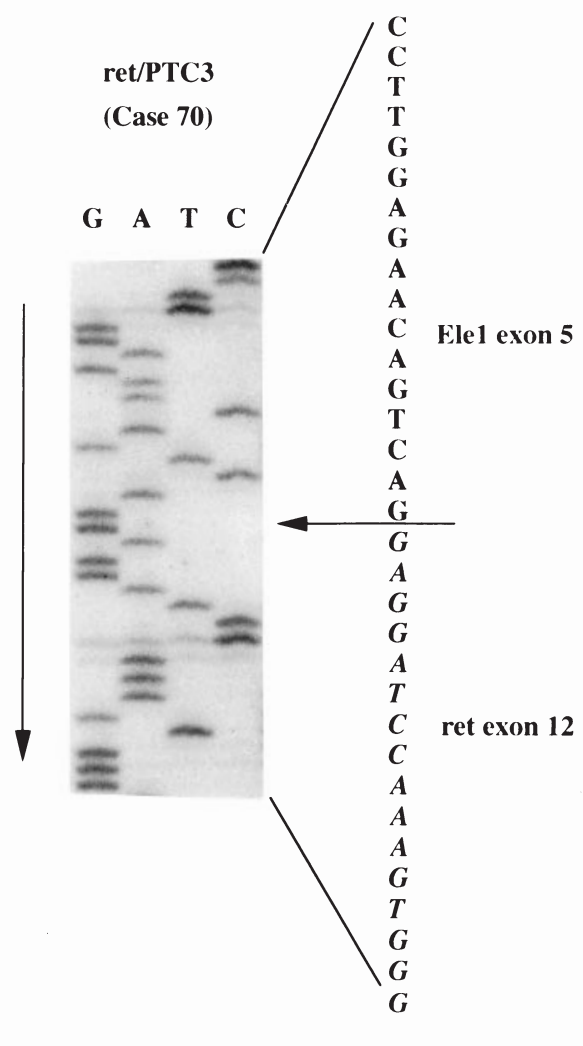

Fig. 3 Nucleotide and predicted amino acid sequence of novel fusion cDNA involving the $R E T$ gene detected in tumor 28 . The novel sequence in the $5^{\prime}$ portion is underlined. The $3^{\prime}$ portion represents the RET sequence starting from exon 12, Arrowheads indicates the fusion point
TCTGAAAGAGCATGCTTCTTCTCTGGCATCCTCAGGACTGAAAAAGGACTCACGG

$\begin{array}{llllllllllllllllll}\mathrm{L} & \mathrm{K} & \mathrm{E} & \mathrm{H} & \mathrm{A} & \mathrm{S} & \mathrm{S} & \mathrm{L} & \mathrm{A} & \mathrm{S} & \mathrm{S} & \mathrm{G} & \mathrm{L} & \mathrm{K} & \mathrm{K} & \mathrm{D} & \mathrm{S} & \mathrm{R}\end{array}$

CTTAAGACACTAGAGATTGCTTTGGAGCAGAAGAAGGAGGAGTGTCTGAAAATG

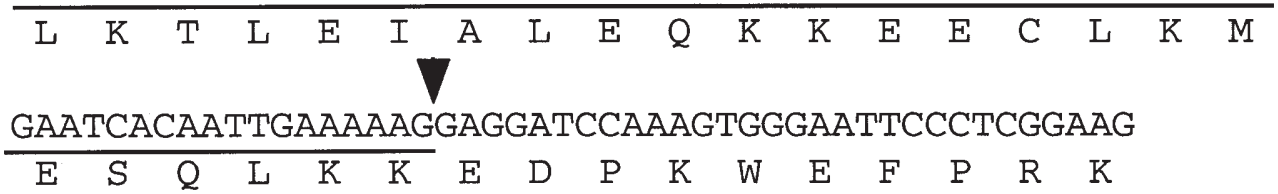

specific for $\mathrm{H} 4, \mathrm{RI} \alpha$, or Ele1 gene sequences. Figure 2A shows representative autoradiograms from these experiments; RT-PCR products hybridized to the $\mathrm{H} 4$ probe in two cases (56 and 86), to the RI $\alpha$ probe in one case (60), and to the Ele1 probe in six cases $(26,70,76,80,88$, and 96). On the basis of these results, we assumed that nine of the ten fusion transcripts resulted from rearrangements of the $R E T$ protooncogene, namely, ret/PTC1, ret/PTC2, and ret/PTC3, respectively. Nucleotide sequencing of the cloned PCR products from the nine cases confirmed that the $5^{\prime}$ donor sequences were from the H4, RIa, or Elel genes (reprensentative autoradiogram shown in Fig. 2B). In the remaining tumor (No. 28), a novel type of $R E T$ rearrangement was identified in the 5' RACE product. The nucleotide and amino acid sequence of this novel fusion $5^{\prime}$
RACE product, $180 \mathrm{bp}$ in size, is shown in Fig. 3. In this tumor, the $5^{\prime}$ novel sequence was fused in-frame to the $R E T$ amino acid sequence starting from exon 12 of the $R E T$ gene. Thus, the fusion gene may encode a protein with a RET kinase domain at the carboxy terminus. The $5^{\prime}$ portion of the fusion product had hydrophobic amino acid residues periodically every seven residues, suggesting that the product may form heptad repeats in the helical-domain structure. In our 40 papillary thyroid carcinomas from Japanese patients, therefore, ret/PTC1 was identified in 2, ret/PTC2 in 1, ret/PTC3 in 6, and a novel RET rearrangement in 1. Table 2 summarizes the genetic abnormalities identified in our panel of tumors. No products from the $5^{\prime}$ RACE and RT-PCR experiments hybridized to a $T R K$-specific probe or to tropomyosin, TPR, or TFG-specific probes. 
Table 2 Molecular structure of the RET rearrangements identified in this study

\begin{tabular}{lllll}
\hline & & & \multicolumn{2}{l}{ Characterization of the fusion point } \\
\cline { 3 - 5 }$R E T$ fusion gene & Frequency & Case no. & $5^{\prime}$ Terminal sequence & $3^{\prime}$ Terminal sequence \\
\hline ret/PTC1 & $2 / 40$ & 56,86 & $3^{\prime}$ End of exon 1 of H4 & $5^{\prime}$ End of exon 12 of $R E T$ \\
ret/PTC2 & $1 / 40$ & 60 & Codon 1-236 of RIa & $5^{\prime}$ End of exon 12 of $R E T$ \\
ret/PTC3 & $6 / 40$ & $26,70,76,80,88,96$ & $3^{\prime}$ End of exon 5 of Ele1 & $5^{\prime}$ End of exon 12 of $R E T$ \\
Unknown & $1 / 40$ & 28 & Undescribed sequence & $5^{\prime}$ End of exon 12 of $R E T$ \\
Total & $10 / 40(25 \%)$ & & & \\
\hline
\end{tabular}

\section{Discussion}

Thyroid cancers are classified as either medullary, papillary, follicular, or anaplastic carcinomas. Medullary carcinoma is derived from parafollicular $\mathrm{C}$ cells; the other types originate from follicular cells of the thyroid gland. Germline missense mutations that activate the RET proto-oncogene initiate familial medullary thyroid carcinomas, including those found in multiple endocrine neoplasia type 2 (Donis-Keller et al. 1993; Mulligan et al. 1993; Kitamura et al. 1995; Kitamura et al. 1997). Somatic missense mutations of the $R E T$ gene are found in sporadic medullary thyroid carcinomas as well (Hofstra et al. 1994; Kitamura et al. 1997). The loss of heterozygosity $(\mathrm{LOH})$ in specific chromosomal regions that is frequently detected in follicular (Tung et al. 1997) and anaplastic thyroid carcinomas, but not in medullary or papillary thyroid carcinomas, implicates a number of different tumor suppressor genes in those tumors. However, there is no evidence to support the idea that inactivation of these tumor suppressors plays a role in the development of papillary thyroid carcinomas, which comprise the majority of thyroid cancers (Ward et al. 1998). This remarkable contrast in $\mathrm{LOH}$ frequencies suggests a fundamental difference in the genetic basis of tumorigenesis in papillary thyroid carcinomas and other types of thyroid cancer.

Three forms of $T R K$ rearrangement have been reported in papillary thyroid carcinomas (Bongarzone et al. 1989), but in our panel of tumors we detected no rearrangements involving the $T R K$ gene. Three forms of somatic rearrangement previously reported in the RET gene (ret/PTC1, ret/ PTC2, and ret/PTC3), however, did appear in our papillary thyroid carcinomas, in which the tyrosine kinase domain of $R E T$ was fused to the $5^{\prime}$ terminal sequences of genes encoding $\mathrm{H} 4$, regulatory subunit $\mathrm{RI} \alpha$ of protein kinase $\mathrm{A}$, and Ele1, respectively. The ret/PTC1 and ret/PTC3 oncogenes result from a paracentric inversion of the long arm of chromosome 10 (Pierotti et al. 1992; Minoletti et al. 1994). The genomic breakpoints of the $R E T$ proto-oncogene in all three forms of RET rearrangement occur within intron 11; the genomic breakpoints of ret/PTC1 and ret/PTC3 are known to occur within intron 1 of the $H 4$ gene and intron 5 of the Ele1 gene, respectively (Smanik et al. 1995). At the cDNA level, therefore, exon 12 of RET (the first of the exons encoding the RET tyrosine kinase domain) is fused to $5^{\prime}$ coding sequences of the donor genes (exon 1 of $\mathrm{H} 4$, methionine at position 236 of RIa, and exon 5 of Ele1). Recently, an exceptional case, ret/PTC4 in which exon 11 of $R E T$, instead of exon 12, rearranged with exon 5 of Ele1, was observed in papillary thyroid carcinomas from children in Belarus after the Chernobyl reactor accident (Fugazzola et al. 1996; Klugbauer et al. 1996). In our series, the cDNAs of all ret/PTC1, ret/PTC2, and ret/PTC3 oncogenes identified had identical RET fusion points at the start of exon 12.

In a study reported by Bongarzone et al. (1994), RET rearrangements were detected in 18 of 52 papillary thyroid carcinomas from Italian patients $(35 \%)$ : there were 10 cases of ret/PTC1, 2 of ret/PTC2, and 6 of ret/PTC3. The ret/ PTC1 oncogene is generally the most frequent form of RET rearrangement found in Caucasian populations, although the precise frequency varies with different studies (Jhiang et al. 1992; Santoro et al. 1992; Williams et al. 1996; Bounacer et al. 1997). In Japan, Namba et al. (1991) examined ten papillary thyroid carcinomas only for ret/PTC1 rearrangements and found no rearrangement; Ishizaka et al. (1991) found one ret/PTC1 rearrangement among 11 carcinomas, and Wajjwalku et al. (1992) found only one such alteration among 38 carcinomas. On the basis of those observations, RET gene rearrangements in papillary thyroid carcinomas were thought to be rare in the Japanese population. Recently, Motomura et al. (1998) detected previously described RET rearrangements (which included five cases of ret/PTC1 and two cases of ret/PTC3) in 4 of 11 Japanese adult patients and 3 of 10 Japanese children with papillary thyroid carcinomas. In our panel of 40 adult patients, ret/ PTC3 was the most frequent $R E T$ rearrangement. This may be due to differences in the etiology of carcinogenesis between childhood and adult cancers.

As not only ret/PTC1 but also other types of gene rearrangements involving RET or TRK have been identified recently in papillary thyroid carcinomas in Caucasians, we systematically screened a panel of Japanese papillary thyroid carcinomas for all possible types of rearrangement involving $R E T$ or $T R K$ genes, using 5' RACE in addition to RT-PCR. The results reported here show that RET rearrangements are indeed, common $(25 \%)$ in Japanese patients, and that ret/PTC3 is the most frequent type of fusion gene in this study population. No TRK rearrangement was detected in this study, although we cannot rule out the remote possibility of experimental failure that may have led to the apparent lack of TRK fusion. We also identified a novel type of fusion gene involving RET. Since the $5^{\prime}$ portion of this fusion product had hydrophobic amino acid 
residues periodically at every seven residues, it is possible that this domain may form heptad repeats in the helicaldomain structure, often observed in the coiled-coil structure of proteins that are capable of forming dimers. The $3^{\prime} R E T$ portion of the fusion protein could have a $R E T$ kinase domain at the carboxy terminus. Future characterization of the novel gene will eventually clarify the detailed structural arrangement of this fusion event and its consequences, which may explain the carcinogenetic mechanisms in this type of rearrangement.

The follicular cells from which papillary thyroid carcinomas arise do not normally express RET transcripts (Fabien et al. 1992). However, ubiquitously expressed promoters of the $H 4, R I \alpha$, or Ele1 genes that have been rearranged would likely result in the ectopic expression of the RET tyrosine kinase (Bongarzone et al. 1994) in tumors derived from follicular cells. Receptor-type tyrosine kinases are activated by dimerization (Ullrich and Schlessinger 1990). In the normal state, RET reversibly dimerizes, activating its kinase, only when its ligands (GDNF and NTN) stimulate their receptors that have complexed with $R E T$. Constitutive dimer formation, mediated by the dimerization domain of the $5^{\prime}$ portion of each rearranged ret/PTC oncogene, would lead to the activation of $R E T$ tyrosine kinase at the $3^{\prime}$ end of the fused gene (Bongarzone et al. 1993). Therefore, the respective ret/PTC chimeric proteins would bring about constitutive activation of tyrosine kinase; subsequent autophosphorylation of key tyrosine residues (Bongarzone et al. 1993; Bongarzone et al. 1994) would ultimately lead to cellular transformation. Others have shown that thyroid tumors resembling human papillary thyroid carcinomas will arise when transgenic mice are engineered to overexpress the ret/PTC1 oncogene (Jhiang et al. 1996; Santoro et al. 1996). This functional evidence that the $R E T$ gene-fusion event participates in cellular transformation, together with the molecular characterization of rearrangements in a substantial proportion of primary papillary thyroid carcinomas in the present study and elsewhere, implicates the etiological significance of RET rearrangement in the development of papillary thyroid carcinoma, regardless of race or population.

Acknowledgments Supported by a Grant-in-Aid for Cancer Diagnosis and Treatment from the Ministry of Education, Science, Sports, and Culture of Japan; by a Grant-in-Aid for Cancer Research from the Ministry of Health and Welfare of Japan; and by Novartis Research Grants for Promotion of Science.

\section{References}

Bongarzone I, Pierotti M, Monzini N, Mondellini P, Manenti G, Donghi R, Pilotti S, Grieco M, Santoro M, Fusco A, Vecchio G, Della Porta G (1989) High frequency of activation of tyrosine kinase oncogenes in human papillary thyroid carcinoma. Oncogene 4: 14571462

Bongarzone I, Monizini N, Borrello M, Carcano C, Ferraresi G, Arighi E, Mondellini P, Della Porta G, Pierotti M (1993) Molecular characterization of a thyroid tumor-specific transforming sequence formed by the fusion of ret tyrosine kinase and the regulatory subunit RI $\alpha$ of cyclic AMP-dependent protein kinase A. Mol Cell Biol 13: 358-366
Bongarzone I, Butti M, Coronelli S, Borrello M, Santoro M, Mondellini P, Pilotti S, Fusco A, Della Porta G, Pierotti M (1994) Frequent activation of ret protooncogene by fusion with a new activating gene in papillary thyroid carcinomas. Cancer Res 54: 29792985

Bounacer A, Wicker R, Caillou B, Cailleux A, Sarasin A, Schlumberger M, Suarez H (1997) High prevalence of activating ret proto-oncogene rearrangements, in thyroid tumors from patients who had received external radiation. Oncogene 15: 1263-1273

Chen Z (1996) Simple modifications to increase specificity of the 5' RACE procedure. Trends Genet 12: 87-88

Chomczynski P, Sacchi N (1987) Single-step method of RNA isolation by acid guanidinium thiocyanate-phenol-chloroform extraction. Anal Biochem 162: 156-159

Donis-Keller H, Dou S, Chi D, Carlson KM, Toshima K, Laimore TC, Howe JR, Moley JF, Goodfellow PJ, Wells SA Jr (1993) Mutations in the RET proto-oncogene are associated with MEN 2A and FMTC. Hum Mol Genet 2: 851-856

Fabien N, Paulin C, Santoro M, Berger N, Grieco M, Galvain D, Barbier Y, Doubois P, Fusco A (1992) Detection of RET oncogene activation in human papillary thyroid carcinomas by in situ hybridization. Br J Cancer 66: 1094-1098

Fugazzola L, Pierotti M, Vigano E, Pacini F, Vorontsova T, Bongarzone I (1996) Molecular and biochemical analysis of RET/ PTC4, a novel oncogenic rearrangement between RET and ELE1 genes, in a post-Chernobyl papillary thyroid cancer. Oncogene 13: 1093-1097

Greco A, Pierotti M, Bongarzone I, Pagliardini S, Lanzi C, Della Porta G (1992) TRK-T1 is a novel oncogene formed by the fusion of TPR and TRK genes in human papillary thyroid carcinomas. Oncogene 7: 237-242

Greco A, Mariani C, Miranda C, Lupas A, Pagliardini S, Ponati M, Pierotti M (1995) The DNA rearrangement that generates the TRK$\mathrm{T} 3$ oncogene involves a novel gene on chromosome 3 whose product has a potential coiled-coil domain. Mol Cell Biol 15: 6118-6127

Grieco M, Santoro M, Berlingieri M, Melillo R, Donghi R, Bongarzone I, Pierotti M, Della Porta G, Fusco A, Vecchio G (1990) PTC is a novel rearranged form of the ret proto-oncogene and is frequently detected in vivo in human thyroid papillary carcinomas. Cell 60: 557563

Hofstra RMW, Landsvater RM, Ceccherini I, Stulp RP, Stelwagen T, Luo Y, Pasini B, Höppener JWM, van Amstel HKP, Romeo G, Lips CJM, Buys CHCM (1994) A mutation in the RET proto-oncogene associated with multiple endocrine neoplasia type $2 \mathrm{~B}$ and sporadic medullary thyroid carcinoma. Nature 367 : $375-376$

Ishizaka Y, Kobayashi S, Ushijima T, Hirohashi S, Sugimura T, Nagao M (1991) Detection of retTPC/PTC transcripts in thyroid adenomas and adenomatous goiter by an RT-PCR method. Oncogene 6: 16671672

Jhiang S, Caruso D, Glimore E, Ishizaka Y, Tahira T, Nagao M, Chiu I, Mazzaferri E (1992) Detection of the PTC/ret ${ }^{\mathrm{TPC}}$ oncogene in human thyroid cancers. Oncogene 7: 1331-1337

Jhiang S, Smanik P, Mazzaferri E (1994) Development of a single-step duplex RT-PCR detecting different forms of ret activation, and identification of the third form of in vivo ret activation in human papillary thyroid carcinoma. Cancer Lett 78: 69-76

Jhiang S, Sagartz J, Tong Q, Parker T, Capen C, Cho J, Xing S, Ledent C (1996) Targeted expression of the ret/PTC1 oncogene induces papillary thyroid carcinomas. Endocrinology 137: 375-378

Jing S, Wen D, Yu Y, Holst P, Lou Y, Fang M, Tamir R, Antonio L, Hu Z, Cupples R, Louis J, Hu S, Altrock B, Fox G (1996) GDNFinduced activation of the ret protein tyrosine kinase is mediated by GDNFR-alpha, a novel receptor for GDNF. Cell 85: 1113-1124

Kitamura Y, Scavarda N, Wells SA Jr, Jackson C, Goodfellow PJ (1995) Two maternally derived missense mutations in the tyrosine kinase domain of the RET protooncogene in a patient with de novo MEN 2B. Hum Mol Genet 4: 1987-1988

Kitamura Y, Goodfellow PJ, Shimizu K, Nagahama M, Ito K, Kitagawa W, Akasu H, Takami H, Tanaka S, Wells SA Jr (1997) Novel germline RET proto-oncogene mutations associated with medullary thyroid carcinoma (MTC): Mutation analysis in Japanese patients with MTC. Oncogene 14: 3103-3106

Klein R, Jing S, Nanduri V, O'Rourke E, Barbacid M (1991) The trk proto-oncogene encodes a recptor for nerve growth factor. Cell 65: 189-197 
Klein R, Sherman D, Ho WH, Stone D, Bennett GL, Moffat B, Vandlen R, Simmons L, Gu Q, Hongo JA, Devaux B, Poulsen K, Armanini M, Nozaki C, Asai N, Goddard A, Phillips H, Henderson CE, Takahashi M, Rosenthal A (1997) A GPI-linked protein that interacts with Ret to form a candidate neurturin receptor. Nature 387: 717-721

Klugbauer S, Lengfelder E, Demidchik E, Rabes H (1996) A new form of RET rearrangement in thyroid carcinomas of children after the Chernobyl reactor accident. Oncogene 13: 1099-1102

Martin-Zanca D, Hughes S, Barbacid M (1986) A human oncogene formed by the fusion of truncated tropomyosin and protein tyrosine kinase sequences. Nature 319: 743-748

Minoletti F, Butti M, Coronelli S, Miozzo M, Sozzi G, Pilotti S, Tunnacliffe A, Pierotti M, Bongarzone I (1994) The two genes generating RET/PTC3 are localized in chromosomal band 10q11.2. Genes Chromosom Cancer 11: 51-57

Motomura T, Nikiforov YE, Namba H, Ashizawa K, Nagataki S, Yamashita S, Fagin JA (1998) ret Rearrangements in Japanese pediatric and adult papillary thyroid cancers. Thyroid 8: 485-489

Mulligan LM, Know JBJ, Healey CS, Elsdon MJ, Eng C, Gardner E, Love DR, Mole SE, Moore JK, Papi L, Ponder MA, Telenius H, Tunnacliff L, Ponder BAJ (1993) Germ-line mutations of the RET proto-oncogene in multiple endocrine neoplasia type 2A. Nature 363: 458-460

Nakamura Y (1993) Multi-step carcinogenesis of colorectal cancer. Jpn J Hum Genet 38: 23-24

Nakamura Y (1996) Application of DNA markers to clinical genetics. Jpn J Hum Genet 41: 1-14

Namba H, Yamashita S, Pei H, Ishikawa N, Villadolid M, Tominaga T, Kimura H, Tsuruta M, Yokoyama N, Izumi M, Ishigaki J, Ito K, Nagataki S (1991) Lack of PTC gene (ret proto-oncogene rearrangement) in human thyroid tumors. Endocrinol Japon 38: 627-632

Pierotti M, Santoro M, Jenkins R, Sozzi G, Bongarzone I, Grieco M, Monzini N, Miozzo M, Herrmann M, Fusco A, Hay I, Della Porta G, Vecchio G (1992) Characterization of an inversion on the long arm of chromosome 10 juxtaposing D10S170 and ret and creating the oncogenic sequence ret/ptc. Proc Natl Acad Sci USA 89: 1616-1620

Rabbits T (1994) Chromosomal translocations in human cancer. Nature 372: 143-149

Santoro M, Cariomagno F, Hay I, Herrmann M, Grieco M, Melillo R, Pierotti M, Bongarzone I, Della Porta G, Berger N, Peix J, Paulin C,
Fabien N, Vecchio G, Jenkins R, Fusco A (1992) Ret oncogene activation in human thyroid neoplasms is restricted to the papillary cancer subtype. J Clin Invest 89: 1517-1522

Santoro M, Dathan N, Berlingieri M, Bongarzone I, Paulin C, Grieco M, Pierotti M, Vecchio G, Fusco A (1994) Molecular characterization of RET/PTC3; a novel rearranged version of the RET protooncogene in a human thyroid papillary carcinoma. Oncogene 9: 509-516

Santoro M, Chiappetta G, Cerrato A, Salvatore D, Zhang L, Manzo G, Picone A, Portella G, Giovanni S, Vecchio G, Fusco A (1996) Development of thyroid papillary carcinomas secondary to tissue-specific expression of the ret/PTC1 oncogene in transgenic mice. Oncogene 12: $1821-1826$

Smanik P, Furminger T, Mazzaferri E, Jhiang S (1995) Breakpoint characterization of the ret/PTC oncogene in human papillary thyroid carcinoma. Hum Mol Genet 4: 2313-2318

Tsukamoto K, Haruta K, Shiba T, Emi M (1998) Isolation and mapping of a polymorphic CA repeat sequence at the human interleukin 6 locus. J Hum Genet 43: 71-72

Tung WS, Shevlin DW, Kaleem Z, Tribune DJ, Wells SA Jr, Goodfellow PJ (1997) Allelotype of follicular thyroid carcinomas reveals genetic instability consistent with frequent nonjunctional chromosomal loss. Genes Chromosom Cancer 19: 43-51

Ullrich A, Schlessinger J (1990) Signal transduction by receptors with tyrosine kinase activity. Cell 61: 203-212

Viglietto G, Chiappetta G, Marinez Tello F, Fukunaga F, Tallini G, Rigopoulou D, Visconti R, Mastro A, Santoro M, Fusco A (1995) $\mathrm{RET} / \mathrm{PTC}$ oncogene activation is an early event in thyroid carcinogenesis. Oncogene 11: 1207-1210

Wajjwalku W, SN, Hasegawa Y, Miyazaki K, Satoh Y, Funahashi H, Matsuyama M, Takahashi M (1992) Low frequency of rearrangements of the ret and trk proto-oncogenes in Japanese thyroid papillary carcinomas. Jpn J Cancer Res 83: 671-675

Ward L, Brenta G, Medvedovic M, Fagin J (1998) Studies of allelic loss in thyroid tumors reveal major differences in chromosomal instability between papillary and follicular carcinomas. J Clin Endocrinol Metab 83: 525-530

Williams G, Rooney S, Thomas G, Cummins G, Williams E (1996) RET activation in adult and childhood papillary thyroid carcinoma using a reverse transcriptase-n-polymerase chain reaction approach on archival-nested material. Br J Cancer 74: 585-589 